Jurnal Pemikiran \& Penelitian Psikologi

\title{
PSIKOLOGIA
}

p-ISSN: $185-0327$

e-ISSN: $2549-2136$

www.jurnal.usu.ac.id/psikologia

\section{PENGARUH MUSIK RAP TERHADAP KREATIVITAS VERBAL PADA REMAJA}

\section{THE EFFECT OF RAP MUSIC ON VERBAL CREATIVITY IN ADOLESCENTS}

Siti Rizki Kartika dan Ika Sari Dewi

Psikologia: Jurnal Pemikiran \& Penelitian Psikologi

Tahun 2018, Vol. 13, No. 1, hal.50-58

Artikel ini dapat diakses dan diunduh pada:

www.jurnal.usu.ac.id/psikologia

Dipublikasikan oleh:

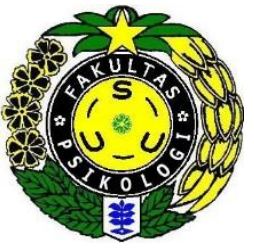

Fakultas Psikologi

Universitas Sumatera Utara

Jl. Dr. Mansyur No. 7 Medan. Telp/fax: 061-8220122

Email: psikologia@usu.ac.id 


\title{
PENGARUH MUSIK RAP TERHADAP KREATIVITAS VERBAL PADA REMAJA
}

\author{
Siti Rizki Kartika dan Ika Sari Dewi \\ Universitas Sumatera Utara
}

\begin{abstract}
ABSTRAK
Kreativitas verbal adalah kemampuan yang terungkap secara verbal, berdasarkan data atau informasi yang berasal dari banyaknya jawaban terhadap masalah, yang terletak pada kuantitas, ketepatgunaan, dan keragaman jawaban (Munandar, 1985). Peningkatan kreativitas verbal dapat dilakukan melalui musik yang mengutamakan teknik verbal. Jenis musik tersebut adalah musik rap. Penelitian ini bertujuan untuk mengetahui pengaruh musik rap terhadap kreativitas verbal pada remaja. Hipotesis yang diajukan adalah terdapat pengaruh musik rap terhadap kreativitas verbal pada remaja. Subjek penelitian ini adalah siswa-siswi kelas X dan kelas XI SMA Negeri 16 Medan sebanyak 28 orang. Untuk memperoleh data digunakan Tes Kreativitas Verbal dari Munandar. Analisa data menggunakan uji statistik non parametrik yaitu Uji Mann Whitney. Hasilnya menunjukkan (1) Terdapat pengaruh musik rap terhadap kreativitas verbal yang ditunjukkan dengan nilai signifikan $.000<.05$ dengan nilai median kelompok eksperimen $(M d n=4)$ lebih tinggi dari kelompok kontrol $(M d n=-1)$. (2) Efeknya yang dihasilkan sebesar $43.56 \%$ dan tergolong large (besar). Dari hasil tersebut dapat disimpulkan bahwa musik rap memiliki pengaruh terhadap kreativitas verbal pada remaja.
\end{abstract}

Kata kunci : Musik Rap, Kreativitas Verbal, Remaja

\section{THE EFFECT OF RAP MUSIC ON VERBAL CREATIVITY IN ADOLESCENTS}

\begin{abstract}
S
Verbal creativity is the ability that expressed verbally, based on data or information derived from many answers toward problem, which site in the quantity, usefulness, and diversity of answers (Munandar, 1985). Increased verbal creativity can be done through music that prioritizes verbal techniques. This type of music is rap music. This study aims to determine the effect of rap music on verbal creativity in adolescents. The hypothesis proposed is that there is rap music influence on verbal creativity in adolescents. The subjects of this study were 28 students of class X and XI of Medan 16 SMA. Obtaining data used Verbal Creativity Test from Munandar. Data analysis uses non parametric statistical tests, Mann Whitney Test. The results show (1) There is rap music influence on verbal creativity which is indicated by a significant value of $.000<.05$ with the median value of the experimental group $(\mathrm{Mdn}=4)$ higher than the control group ( $\mathrm{Mdn}=-1$ ). (2) The resulting effect is $43.56 \%$ and classified as large. From these results it can be concluded that rap music has an influence on verbal creativity in adolescents.
\end{abstract}

Keywords : Rap Music, Creativity, Adolescents.

*Korespondensi mengenai penelitian ini dapat dilayangkan kepada: sitirizkikartika@gmail.com.
Rekomendasi mensitasi:

Kartika, S.R., Dewi, I.S. (2018). Pengaruh Musik Rap Terhadap Kreativitas Verbal pada Remaja. Psikologia :Jurnal Pemikiran dan Penelitian Psikologi, 13(1), 5058 
Kreativitas merupakan salah satu kemampuan mental yang bersifat unik, konkret, maupun abstrak baik verbal maupun non verbal (Hurlock, 1978). Kemampuan yang terungkap secara verbal, berdasarkan data atau informasi yang berasal dari banyaknya jawaban terhadap masalah, yang terletak pada kuantitas, ketepatgunaan, dan keragaman jawaban disebut dengan kreativitas verbal (Munandar, 1985).

Kreativitas verbal individu dapat dilihat melalui keterampilan berbahasa baik lisan maupun tulisan (Munandar, 1985). Keterampilan berbahasa terdiri dari keterampilan menulis, menyimak, berbicara dan membaca (dalam Mulyati, 2015). Adapun beberapa identifikasi keterampilan bahasa menurut Johnson (dalam Munandar,

1999) yaitu mempunyai pembendaharaan kata yang luas, bicara terus-menerus, mempunyai ingatan yang luar biasa, mendeklamasikan ide di luar kepala, memberikan pendapatnya, memahami buku dan diskusi, serta mengajukan beberapa pemecahan untuk masalah yang sama.

Pengembangan keterampilan bahasa di sekolah dapat dilihat dari tugastugas yang diberikan guru di sekolah. Peneliti melakukan survey terhadap 100 siswa-siswi SMA Negeri 16 Medan bahwa guru mereka juga lebih banyak memberikan soal dalam bentuk essay, memberikan tugas bercerita serta adanya beberapa tugas mata pelajaran yang menggunakan metode presentasi dicampur dengan tanya jawab antar siswa yang memberikan kesempatan siswa untuk berdiskusi yang berguna untuk pengembangan bahasa mereka. Menurut Munandar (1999) pembelajaran bahasa di sekolah harus menekankan pengembangan keterampilan kreatif dengan melibatkan siswa dalam pemecahan masalah, memberikan kesempatan siswa untuk mengungkapkan pikiran dan perasaan dalam menulis dan berbicara serta penggunaan tema yang luas dalam presentasi.

Masalahnya yang didapatkan dari hasil survey pada 100 siswa SMA Negeri 16 Medan, terdapat 66 orang siswa yang memiliki kesulitan dalam mengembangkan kata-kata ketika diberi soal essay sehingga jawaban dari pertanyaan yang terlalu berpatokan dengan yang ditulis dibuku. Terdapat juga kesulitan dalam mencari ide sendiri ketika disuruh untuk membuat tugas bercerita. Mereka menyontek beberapa kalimat dengan temannya serta tidak bervariasinya cerita yang dituliskan oleh siswa serta cerita yang mereka buat singkat. Kemampuan menulis paragraf siswa SMA Negeri 16 Medan yang masih tergolong rendah dan kurang memuaskan karena tidak mencapai nilai KKM yaitu 70 (Harahap,

2017). Kemampuan menulis yang dimaksud dalam hal ini adalah memadukan makna antar kalimat yang satu dengan kalimat yang lainnya agar terjalin dengan baik atau tidak (Harahap, 2017). Selain itu hasil wawancara peneliti kepada salah satu siswa SMA Negeri 16 Medan terungkap kalau mereka juga menggunakan metode presentasi dan diskusi pada beberapa mata pelajaran dan memiliki kesulitan saat menyampaikan gagasan saat presentasi dan diskusi. Informasi yang tertera di atas menunjukkan bahwa keterampilan bahasa siswa masih tergolong rendah. Rendahnya keterampilan bahasa yang terjadi pada siswa SMA Negeri 16 Medan mengindikasikan rendahnya kreativitas verbal siswa. 
Menurut Ayan (2002) kemampuan berbahasa yang baik dan benar menunjukkan kreativitas verbal yang baik. Kemampuan tersebut digunakan untuk berkomunikasi secara lisan maupun tulisan yang dilakukan bersamaan dengan proses berpikir, sehingga antara penggunaan bahasa untuk berkomunikasi dengan berpikir terdapat kaitan yang erat. Munandar (1985) juga mengemukakan bahwa kreativitas verbal dapat dikembangkan melalui kegiatan

kegiatan "olah kata" yang berguna mengungkapkan pikiran dan perasaan dengan kata yang baik dan menarik dan itu memerlukan keterampilan berbahasa.

Secara kogntif kreativitas verbal positif berhubungan dengan left inferior frontal gyrus yang mengatur produksi dan pemahaman bahasa, representasi semantik baru dan juga berhubungan dengan right inferior frontal gyrus yang mengatur pengalihan perhatian dan mengontrol penghambatan. Secara keseluruhan, individu yang memiliki kreativitas verbal yang baik dapat menunjukkan efisiensi yang lebih besar di daerah otak yang terlibat dalam proses kognitif termasuk produksi bahasa, representasi semantik dan kontrol kognitif (Zhu, Zhang dkk, 2013).

Terkait dengan adanya indikasi rendahnya kreativitas verbal pada siswa yang dilihat dari rendahnya keterampilan bahasa mereka didukung oleh penelitian dari University Tibiscus yang melakukan penelitian terhadap 105 high school students yang menyatakan bahwa kreativitas verbal pada high school lebih rendah daripada kreativitas figural mereka (Gaspar, 2012).

Masih rendahnya kreativitas verbal pada siswa SMA berkaitan juga dengan bagian otak yang disebut prefrontal cortex yaitu level tertinggi dari frontal cortex yang bertugas dalam pengambilan keputusan, kreativitas, kontrol diri yang belum berkembang sempurna dan masih terus berkembang hingga usia 18 hingga 25 tahun (Santrock, 2009).

Salah satu sarana untuk meningkatkan kemampuan otak dalam hal kreativitas dapat melalui dengan musik. Menurut Merrit (2003) manfaat musik antara lain meningkatkan daya ingat dan merangsang kreativitas. Kreativitas dapat ditingkatkan dengan musik, sehingga siswa SMA yang memiliki kreativitas verbal yang rendah dapat meningkatkan kemampuan mereka dengan memberikan rangsangan musik yang mengutamakan teknik secara verbal. Musik yang bergantung pada kinerja lisan dan kemampuan verbal adalah musik rap (Rose, 1994).

Musik rap adalah syair dengan beat (Escher, 2006). Menurut Rakim (dalam Escher, 2006) bahwa rap adalah irama dan puisi. Menurut Rose (1994) musik rap adalah bentuk cerita berirama serta musik berbasis elektronik. Musik rap mempunyai manfaat untuk meningkatkan perkembangan otak dalam hal kreativitas dimana karakteristik dari musik rap adalah improvisasi lirik dan flow.

Penelitian dari Beaty (2015) mengatakan bahwa improvisasi berkaitan dengan peningkatan pada bagian otak yaitu left inferior frontal gyrus selama tugas untuk menghasilkan ide- ide kreatif. Ketika individu bermain musik rap dan nge-flow, gelombang beta bergerak cepat dari kesadaran menuju ke pergerakan lambat antara gelombang alpha dan gelombang 
theta pada saat itulah ide-ide dikombinasikan (Kotler, 2014). Bagian prefrontal cortex dinonaktifkan sementara tepatnya dibagian dorsolateral prefrontal cortex hasilnya individu jauh lebih berani, kritis, serta meningkatkan kemampuan membayangkan kemungkinan yang baru. Serta hormon- hormon yang dapat menimbulkan kesenangan yang berdampak cukup terhadap kreativitas yaitu dopamine, endorphin dan norepinefrin menjadi aktif dimana hormon tersebut meningkatkan kemungkinan kemungkinan imajinatif (Kotler, 2014).

Terdapat juga penelitian yang menunjukkan musik rap dapat merangsang kreativitas. Hasil penelitian dari National Institute on Deafness and Other Communication Disorder dan National Institute of Health bahwa ditemukan adanya penonaktifan meliputi frontal eye dan contiguous portions dari dorsolateral prefrontal cotex dan dorsal premotor yang mengatur pengawasan dan pemantauan. Improvisasi dengan memadukan lirik danmusik memicu otak semakin kreatif dimana aktivitas tinggi pada frontal cortex (Liu, 2012).

Berdasarkan hasil uraian sebelumnya dan hasil penelitian mengenai musik rap menjadi dasar mengapa peneliti memutuskan untuk melakukan penelitian mengenai music rap.

\section{METODE}

Penelitian ini menggunakan metode true experiment dengan rancangan pretest-posttest between subject design. Subjek yang terlibat dalam penelitian ini adalah 28 orang yang terbagi kedalam 13 orang kelompok eksperimen dan 15 kelompok kontrol. Subjek penelitian ini adalah siswa-siswi SMA Negeri 16 Medan kelas X dan XI yang memiliki kriteria tingkat inteligensi yang sama. Alat ukur yang digunakan dalam penelitian ini adalah Tes Kreativitas Verbal (TKV) oleh Munandar. TKV digunakan untuk mengukur aspek kreativitas yaitu kelancaran, keluwesan, keaslian dan kerincian dalam berpikir. Perlakuan yang diberikan dalam penelitian yaitu latihan musik rap yang dilakukan setiap 3 kali dalam seminggu sebanyak 16 kali pertemuan Berikut rancangan penelitian pretest-posttest between subject design :

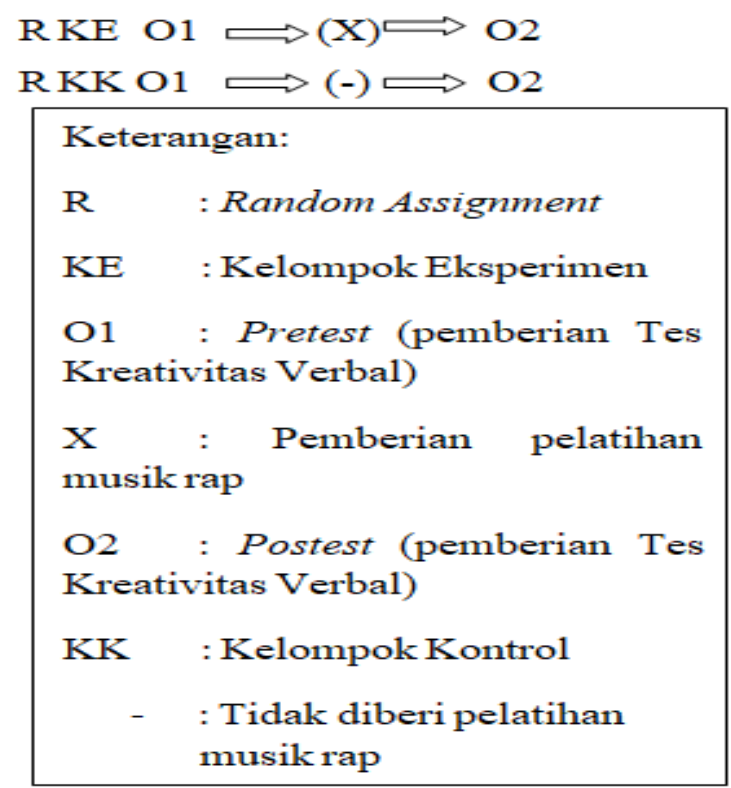

\section{HASIL}

Pengaruh musik rap terhadap kreativitas verbal dilihat dari uji hipotesa dari 28 orang subjek. Uji hipotesa penelitian dilakukan dengan uji statistik nonparametrik- Uji Mann Whitney, di mana peneliti akan membandingkan gain score antara kelompok eksperimen dengan gain score kelompok kontrol. 
Tabel 1. Gambaran statistik umum

\begin{tabular}{ccccc}
\hline Kelompok & N & Median & $\begin{array}{c}\text { Mean } \\
\text { Rank }\end{array}$ & $\begin{array}{c}\text { Standar } \\
\text { Devisasi }\end{array}$ \\
\hline Eksperimen & 13 & 4.000 & 20.31 & 1.67562 \\
Kontrol & 15 & -1.000 & 9.47 & 2.84856 \\
\hline
\end{tabular}

Selanjutnya $\mathrm{H}_{0}$ akan ditolak jika nilai siginifikansi (1-tailed) lebih kecil dari .05 atau $\mathrm{p}<.05$ dengan taraf kepercayaan $95 \%$.

\begin{tabular}{|c|c|c|c|}
\hline U-Mann & Asymp & Z & Sig. (1 \\
\hline Whitney & $\begin{array}{l}\text { Sig. } \\
\text { tailed })\end{array}$ & & tailed) \\
\hline 22.000 & .000 & -3.521 & .000 \\
\hline
\end{tabular}

Berdasarkan hasil uji Mann-

Whitney yang diperoleh melalui program SPSS diketahui bahwa Sig. (1 tailed) .000 $<.05$ dengan taraf kepercayaan 95\%. Ini menunjukkan bahwa terdapat perbedaan kreativitas verbal secara signifikan antara kelompok eksperimen yang diberikan latihan musik rap dengan kelompok kontrol yang tidak diberikan latihan rap. Dapat dilihat dari hasil perbedaan Median pada kedua kelompok dimana kelompok eksperimen $(M d n=4)$ lebih tinggi dari kelompok kontrol $(M d n=-1)$ Ini menunjukkan bahwa kreativitas verbal kelompok eksperimen yang berlatih rap lebih baik daripada kelompok kontrol.

Efect size (r) untuk melihat seberapa besar pengaruh musik rap terhadap kreativitas verbal. Nilai $r$ yang diperoleh oleh penelitian ini adalah -.66. Hal ini menunjukkan besarnya pengaruh musik rap terhadap kreativitas verbal sebesar $(.66)^{2}$ x $100 \%=43.56 \%$. Penjelasannya yaitu efek yang dihasilkan berada pada kategori large (besar) terhadap sampel.
Hasil diatas juga dilengkapi dengan hasil observasi bahwa terjadinya peningkatan jumlah lirik yang awal latihan hanya 2-3 baris menjadi 8 baris. Mereka pun menikmati proses latihan yang ditunjukkan mereka rajin bertanya kepada pelatih, mengerjakan apa yang disuruh oleh pelatih walaupun ada beberapa hari mereka kelelahan.

\section{DISKUSI}

Musik rap adalah syair dengan beat (Escher, 2006). Menurut Rakim dalam Escher (2006) bahwa rap adalah irama dan puisi. Peserta diharuskan untuk membuat lirik dari pemikiran mereka sendiri. Mereka menggabungkan berbagai macam ide yang ada untuk menjadi lirik baru yang disampaikan dengan cara yang unik yaitu menggunakan flow tetapi tetap mengikuti aturan berirama ab atau aa. Hal ini sesuai dengan pendapat Munandar (2012) bahwa kegiatan membuat cerita mengarahkan pada pola berpikir kreatif yang terlihat pada kelancaran, kelenturan, keaslian dan elaborasi dalam menghasilkan kata. Saat para peserta dituntut untuk membuat lirik secara kreatif bagian otak yang berperan dalam kreativitas yang disebut left inferior frontal gyrus menjadi aktif selama pembuatan lirik atau improvisasi yang berguna untuk menghasilkan ide- ide kreatif (Beaty, 2015).

Pelatihan musik rap diberikan dalam beberapa sesi yaitu pemberian materi, latihan membuat lirik, latihan flow, freestyle, dan battle yang berhubungan dengan aspek-aspek kreativitas yaitu kelancaran berpikir dalam membuat lirik, kelenturan dalam penggunaan kata dan membawakan lirik dengan flow, keaslian 
dalam membuat lirik, dan kerincian dalam mengembangkan kata. Latihan rap memberikan kesempatan peserta untuk mengembangkan idenya berupa kata-kata serta dilatih untuk berani dalam membawakan lirik mereka.

Saat latihan peserta mengalami proses bagaimana cara membuat lirik yang baik, cara membawakan lirik dengan flow, belajar freestyle dan battle. Para peserta mendapatkan koreksi oleh pelatih hingga akhirnya para peserta mengalami peningkatan dalam membuat lirik dan flow dan mampu menghasilkan lirik dari pemikiran mereka sendiri. Saat latihan, peserta terlihat bersemangat belajar rap ditunjukkan dengan mereka sering bertanya kepada pelatihnya mengenai rap, cara mudah untuk bisa flow, dan bisa atau tidaknya mereka tetap latihan walaupun eksperimen telah selesai. Sejalan dengan pernyataan Torrance (dalam Munandar, 2012) bahwa kreativitas ditinjau dari proses untuk merasakan dan mengamati adanya masalah, menilai dan mengujinya. Ditinjau dari produk apa yang dihasilkan merupakan sesuatu yang baru, asli dan bermakna. Serta ditinjau dari pendorong dimana kreativitas memerlukan dorongan internal dan dorongan eksternal.

Pembuatan lirik rap dibutuhkan informasi-informasi untuk dituangkan ke dalam kata-kata. Awal latihan pembuatan lirik, flow dan freestyle peserta diberikan kebebasan dalam membuat lirik mereka. Setelah hari terakhir dari hari pembuatan lirik, flow dan freestyle peserta disuruh untuk membuat lirik dengan tema "jati diri". Para peserta disuruh untuk menuliskan apa yang mereka rasakan, alami, lihat, dan dengar untuk mereka jadikan sebuah lirik. Peserta berusaha berpikir dan mengingat sambil menggaruk-garuk kepala, melihat ke atas dan melihat ke luar untuk menghasilkan ide-ide.

Sejalan dengan pernyataan Stenberg (1999) bahwa ketika seseorang dihadapkan masalah dibutuhkan informasi untuk menyelesaikannya yang tersimpan di dalam memori dalam bentuk representasi mental simbolik yaitu verbal. Saat masalah tersebut datang, represetasi mental simbolik tersebut dikeluarkan dan bentuk kreativitas verbal.

Hasil observasi peneliti melihat bahwa secara keseluruhan peserta terlihat senang dan bersemangat dalam mengikuti kegiatan latihan walaupun ada beberapa hari mereka terlihat kelelahan, saat awal latihan mereka terlihat gugup dan menolak ketika disuruh tampil ke depan serta kesulitan dalam menghasilkan ide untuk membuat lirik secara spontan. Tetapi dengan seiring berjalannya latihan mereka menjadi mempunyai keberanian dalam melakukan rap dan mampu dalam menghasilkan ide secara spontan walaupun hanya 3 sampai dengan 8 baris. Ini dapat dihubungkan dengan pernyataan dari Kotler (2014) bahwa saat peserta melakukan aktivitas musik rap dengan flow bagian otak yang disebut prefrontal cortex dinonaktifkan sementara tepatnya dibagian dorsolateral prefrontal cortex yang mengendalikan pemantauan diri dan kontrol implus yang membuat peserta menjadi berani. Setelah itu hormonhormon yang dapat menimbulkan kesenangan yang berdampak cukup terhadap kreativitas yaitu dopamine, endorphin dan norepinefrin menjadi aktif dimana hormon tersebut meningkatkan kemungkinan kemungkinan imajinatif dengan mengumpulkan informasi lebih lanjut serta meningkatkan kemampuan untuk menghubungkan ide-ide secara 
bersamaan dengan cara yang baru.

Terkait hasil observasi yang menunjukkan peserta senang dan bersemangat dalam mengikuti latihan dengan sering bertanya kepada pelatih apa yang ingin mereka ketahui mengenai rap, dan bertanya apakah bisa lanjut untuk latihan menunjukkan sejalannya dengan pernyataan dari Santrock (2009) bahwa peserta yang masih dalam usia remaja menggunakan musik sebagai pencarian identitas dengan melakukan hal-hal yang mereka sukai.

Berdasarkan penjelasan hasil penelitian dan beberapa penelitian yang mendukung dapat disimpulkan bahwa musik rap dapat membantu meningkatkan kreativitas verbal remaja cukup efektif. Musik rap memberikan efek pada fungsi kognitif dengan cara dituntut untuk menciptakan lirik sendiri yang membutuhkan ide sehingga akan meningkatkan kemampuan kreativitas verbal.

\section{REFERENSI}

Ayan, J. E. (2002). Bengkel kreativitas 10 cara menemukan ide-ide pamungkas. Bandung: Penerbit Kaifa.

Beaty, R. E. (2015). The neuroscience of musical improvisation. Neuroscience Biobehavioral Reviews 51, 108-117. doi:10.1016/j.neubiorev.2015.01.00 4

Escher, E. (2006). The rapper's handbook a guide to freestyling, writing rhymes and battling. New York: Flocabulary, LLC.

Field, A. (2009). Discovering statistics using

SPSS $3 \quad r d$ ed. London: Sage
Publication.

Gaspar , O. D. (2013). Verbal and figural creativity in contemporary highschool students. Procedia - Social and Behavioral Sciences 78, 662666.

doi:10.1016/j.sbspro.2013.04.371

Harahap, A. P. (2017). Analisis Kepaduan Paragraf pada Teks Eksposisi Siswa Kelas X SMA Negeri 16 Medan TahunPembelajaran 2016/2017. Universitas Negeri Medan. Medan: Digital Repository

Hurlock, E. B. (1978). Child development.Tokyo: Mc. Graw Hill.

Kotler, S. (2016, September 21). Flow states and creativity. Retrieved from Psychology today.com: https://www.psychologytoday.com/bl og/the- playing-field/201402/flowstates-and- creativity

Mulyati, Y. (2015). Keterampilan Berbahasa

Indonesia SD. Universitas Terbuka.

Munandar, U. (2012). Pengembangan kreativitas anak berbakat. Jakarta: Rineka Cipta.

Munandar, U. (1985). Mengembangkan bakat dan kreativitas anak sekolah. Jakarta: PT. Gramedia.

Munandar, S. U. (1999). Kreativitas dan Keberbakatan Strategi Mewujudkan Potensi Kreatif dan Bakat. Jakarta: PT. Gramedia Pustaka Utama.

Papalia, E. (2009). Human development perkembangan manusia edisi 10. Jakarta: Humanika Salemba.

Rose, T. (1994). Black noise rap music and black culture in contemporary America. Hanover and London: Wesleyan University Press.

Santrock, J. W. (2009). Life span development twelfth edition. New York: Mc Graw- Hill 
Sternberg, R. J. (1999). Handbook of creativity. Cambridge: Cambridge University Press.

Zhu, F., Zhang, Q., \& Qiu, J. (2013). Relating inter-individual difference in verbal creative thinking to cerebral structure an optimal voxel-based morphometry. Journal China, 8(11 : e79272). doi:10.1371 